\title{
23. DEEP CRUSTAL GEOTHERMAL MEASUREMENTS, HOLE 504B, DEEP SEA DRILLING PROJECT LEGS 69, 70, 83, AND 92 ${ }^{1}$
}

\author{
Keir Becker, Scripps Institution of Oceanography \\ Marcus G. Langseth, Lamont-Doherty Geological Observatory, Columbia University \\ Richard P. Von Herzen, Woods Hole Oceanographic Institution \\ and \\ Roger N. Anderson and Michael A. Hobart, Lamont-Doherty Geological Observatory, Columbia University
}

\begin{abstract}
We report an extensive suite of geothermal measurements in the deepest borehole yet drilled into the oceanic crust, Hole 504B of the Deep Sea Drilling Project. Located in 5.9 m.y.-old crust of the Costa Rica Rift, Hole 504B was cored during Legs 69 and 70 in late 1979 and Leg 83 in late 1981, to a total depth of $1350 \mathrm{~m}$ beneath the seafloor, through $274.5 \mathrm{~m}$ of sediment and $1075.5 \mathrm{~m}$ of basalt. During the three drilling legs, downhole temperatures were logged 11 times, and the thermal conductivities of 239 sediment and basalt samples were measured. Temperatures were logged a twelfth time during Leg 92 in 1983. The results indicate a dominantly conductive mode of heat transfer through the complete section, at $190 \pm 10 \mathrm{~mW} / \mathrm{m}^{2}$. This is consistent with the predicted plate heat transfer and the hypothesis that the thick sediment cover acts as a seal against hydrothermal circulation of seawater to basement.

For over two years after this sediment seal was penetrated, borehole temperatures were strongly depressed to about $350-370 \mathrm{~m}$, indicating that ocean bottom water was flowing down the hole into the upper $\sim 100 \mathrm{~m}$ of basement. This downhole flow was driven by the underpressure of the basement pore fluids, which is of indefinite, but possibly hydrothermal origin (Anderson and Zoback, 1982). The flow rate decreased from an initial rate of $6000-7000 \mathrm{~L} / \mathrm{hr}$. in late 1979 to $1500-2000 \mathrm{~L} / \mathrm{hr}$. two years later, and to only $150-200 \mathrm{~L} / \mathrm{hr}$. nearly three and a half years after the flow began. Altogether over $50 \times 10^{6} \mathrm{~kg}$ of seawater has been drawn into the basement. We estimate a permeability of $\geq 6 \times 10^{-14}$ $\mathrm{m}^{2}$ for the reservoir in the upper $\sim 100 \mathrm{~m}$ of basement. This zone seems to correspond to a layer of high apparent porosity (Becker et al., 1982), which has been tentatively identified as a thin Layer 2A (Anderson, Honnorez et al., 1982).
\end{abstract}

\section{INTRODUCTION}

The principal objective of the drilling programs on Legs 69, 70, and 83 of the Deep Sea Drilling Project (DSDP) was the assessment of the physical and chemical state of young oceanic crust. Spectacular success was achieved in Hole 504B on the flank of the Costa Rica Rift, where the three legs cored over $1 \mathrm{~km}$ into oceanic basement and completed an extensive suite of geophysical experiments (CRRUST, 1982; Cann, Langseth, Honnorez, Von Herzen, White, et al., 1983; Anderson, Honnorez, et al., 1982; Becker et al., 1982). Detailed geothermal measurements were made in the hole, revealing the heat transfer and hydrogeology throughout nearly $1300 \mathrm{~m}$ of thickly sedimented, young oceanic crust.

Hole 504B is located under $3460 \mathrm{~m}$ of water, in 5.9 m.y.-old crust about $200 \mathrm{~km}$ south of the spreading axis of the Costa Rica Rift (Fig. 1). During late 1979 and late 1981, the hole was first cased through the $274.5 \mathrm{~m}$ of sediment, and then cored to a depth of $1350 \mathrm{~m}$ beneath the seafloor (Fig. 2). The basement penetration of $1075.5 \mathrm{~m}$ was nearly double that of any other oceanic borehole. Leg 83 cored several hundred meters into the

\footnotetext{
${ }^{1}$ Anderson, R. N., Honnorez, J., Becker, K., et al., Init. Repts. DSDP, 83: Washington (U.S. Govt. Printing Office).

2 Addresses: (Becker) Deep Sea Drilling Project, Scripps Institution of Oceanography, La Jolla, 92093; (Langseth, Anderson, Hobart) Lamont-Doherty Geological Observatory, Columbia University, Palisades, NY 10964; (Von Herzen) Woods Hole Oceanographic Institution, Woods Hole, MA 02543.
}

sheeted dikes and massive units of Layer $2 \mathrm{C}$, which underlie $600+\mathrm{m}$ of pillow lavas and minor flows (Fig. 2) (Anderson, Honnorez, et al., 1982). Borehole temperatures were measured 11 times during the three drilling legs to depths as great as $1287.5 \mathrm{~m}$; thermal conductivities were measured on samples recovered from throughout the $1350 \mathrm{~m}$-hole. In addition, Leg 92 reentered Hole 504B during April 1983, for nine days of geophysical experiments, including a twelfth downhole temperature $\log$.

During predrilling site surveys, Langseth et al. (1983) and Hobart et al. (this volume) found the surface heat flow near Site 504 to be quite close to the 190-200 $\mathrm{mW} / \mathrm{m}^{2}$ predicted by conductively cooling plate models (Fig. 3). This result implies that the 274.5-m sediment cover, with a thin basal layer of chert, is sufficiently thick to prevent advective removal of crustal heat by hydrothermal circulation of ocean bottom water through the basement. On the other hand, about $50 \mathrm{~km}$ closer to the axis, basement topography is rougher, the sediment cover is thinner, and measured heat flows are considerably less than predicted (Fig. 3), suggesting vigorous hydrothermal circulation.

Thus, we consider that the crust at Site 504 may have been, prior to DSDP coring, close to full thermal recovery from a probable earlier hydrothermal cooling phase. The process of drilling through the sediment seal then disturbed this state; both the prior equilibrium state and the newly induced disturbances were of interest. Bore- 


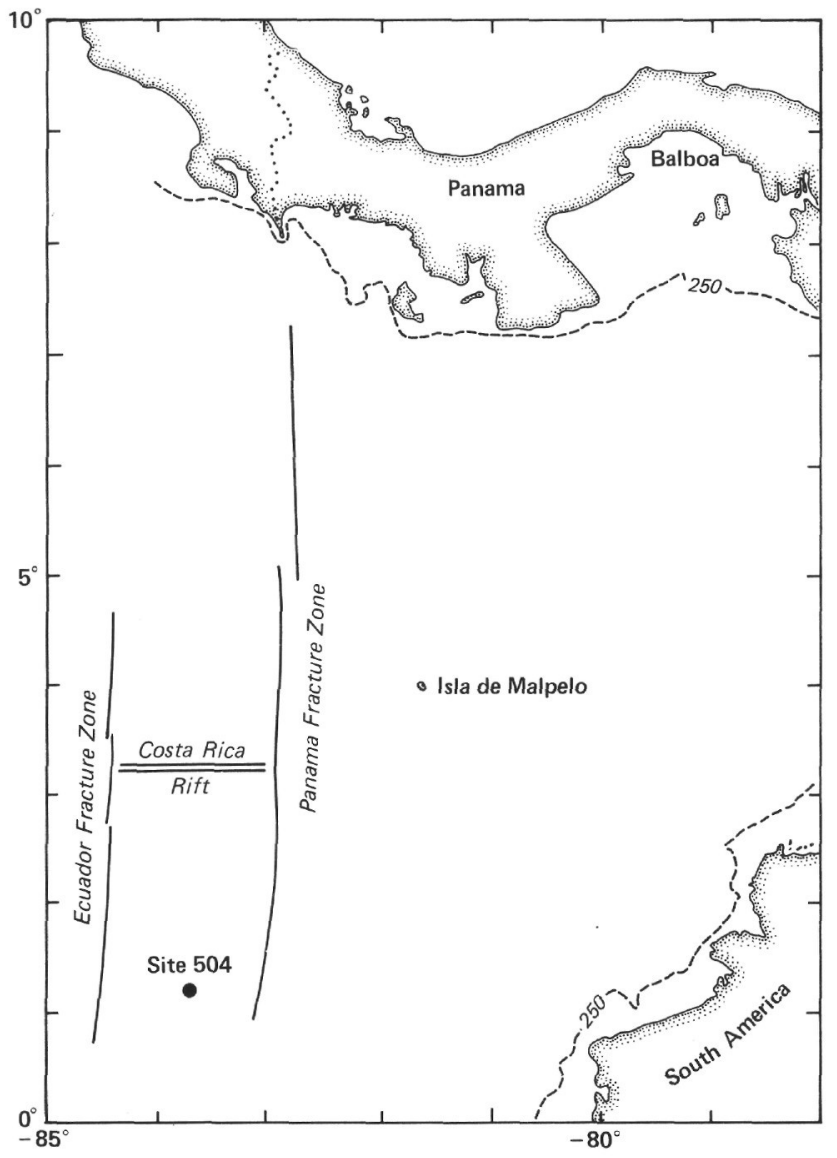

Figure 1. Location of Hole 504B in the eastern equatorial Pacific.

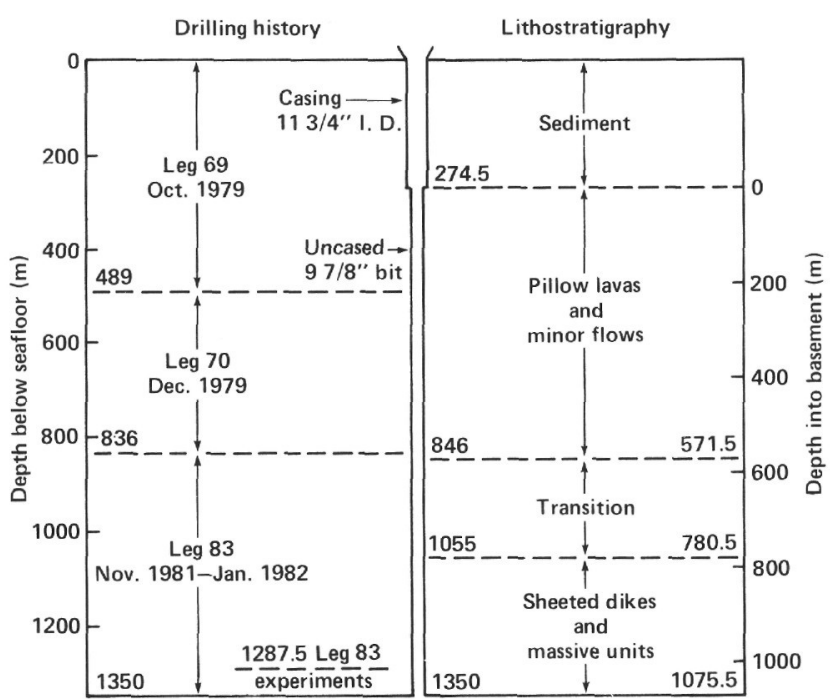

Figure 2. Schematic of the drilling history and lithostratigraphy of Hole 504B.

hole temperature measurements were especially pertinent in this situation, since we could deduce from them both the past undisturbed geothermal state and the subsequent modes of heat transfer and water circulation in the hole and surrounding crust.

\section{METHODS}

\section{Temperature Measurements}

Temperature in Hole 504B were logged 12 times during Legs 69, 70,83 , and 92 , using four different tools. During these measurements, the hole was at various stages of thermal equilibrium or disequilibrium because of the drilling process. Table 1 summarizes the equipment used and the state of the hole during each of these measurements. Four of the 12 measurements were particularly valuable, having been made under equilibrium conditions: (1) the sediment temperatures measured in Hole 504C, offset $\sim 60 \mathrm{~m}$ from Hole 504B; (2) borehole temperatures measured immediately on Leg 70 reentry of the hole, six weeks after the end of Leg 69 basement drilling; (3) borehole temperatures measured immediately on Leg 83 reentry, nearly two years after the Leg 70 drilling disturbance; and (4) borehole temperatures measured immediately on Leg 92 reentry, over 15 months after the Leg 83 drilling disturbance. These measurements were made with the DSDP downhole temperature probe (T-probe) (Yokota et al., 1980); during Leg 92 , temperatures to $400 \mathrm{~m}$ were simultaneously measured with the T-probe and the Von Herzen hydraulic piston corer temperature tool (HPC tool).

In addition, after the cessation of drilling on each of Legs 70 and 83, pairs of continuous temperature logs were run sufficiently long apart to allow extrapolation to equilibrium geothermal conditions. These measurements were made with commercial temperature logging equipment, the Gearhart-Owen differential temperature log (GO-DT) on Legs 69 and 70, and the Schlumberger high resolution temperature log (S-HRT) on Leg 83.

These tools and the procedures used are described in detail by Becker, Langseth, and Von Herzen (1983) and in Hole 504B summary chapters (this volume, and Leinen, Rea, et al., in press). (See, also, Erickson et al., 1975.) Relevant tool properties are summarized in Table 2. All data were obtained on downgoing runs to minimize the disturbance to borehole temperatures. The T-probe, GO-DT, and HPC sensors were mounted in the leading probes of the tools and were taken to monitor undisturbed temperatures. However, a 1-m-long sinker bar was mounted ahead of the S-HRT sensor, which apparently caused some mixing of borehole fluids about the tool, resulting in relatively large possible errors in the S-HRT readings $\left( \pm 2^{\circ} \mathrm{C}\right)$. This probably affected the accuracy of our subsequent data interpretation, particularly in the deeper Leg 83 section of the hole. In the deep, hot $\left(>100^{\circ} \mathrm{C}\right.$ ) section, the Leg $92 \mathrm{~T}$-probe readings showed a strong negative drift of apparent temperatures with time, such that the highest recorded temperature was taken to be a poorly determined minimum value for the in situ temperature. Nevertheless, in light of both the high heat flow at this site and the vigorous movement of water that we observed in the hole, the combined temperature and depth errors for all the instruments used were not critical to our conclusions.

\section{Thermal Conductivity Measurements}

Over 200 thermal conductivity measurements were made in the shipboard laboratory on recovered samples. Wilkens and Langseth (1983) report 120 values on sediments from Hole 504, about 250 m southwest of Hole 504B. Karato et al., (1983) measured conductivities of 61 homogeneous basalt samples from the Leg 69 and 70 sections of the hole $(274.5-836 \mathrm{~m})$. We measured 58 homogeneous basalt samples from the Leg 83 section $(836-1350 \mathrm{~m}$ ) (Hole 504B summary chapter, this volume). All of these measurements were made with a needle-probe apparatus (Von Herzen and Maxwell, 1959), with an estimated accuracy of $\pm 5 \%$. The basalt samples were measured using a half-space adaptation of this method (Carvalho et al., 1980), which requires calibration by means of a standard. During Leg 83 the conductivity of a fused silica standard $\left(1.38 \mathrm{Wm}^{-1} \mathrm{~K}^{-1}\right)$ was determined repeatedly with an accuracy of $\pm 2 \%$.

\section{DATA INTERPRETATION}

As noted previously, the temperature measurements in Hole 504B were taken under various conditions of thermal equilibrium or disequilibrium due to the drilling process. Nevertheless, when any of the 11 borehole temperature logs in Hole 504B were compared to the conductive temperature profile in the sediments of Hole 

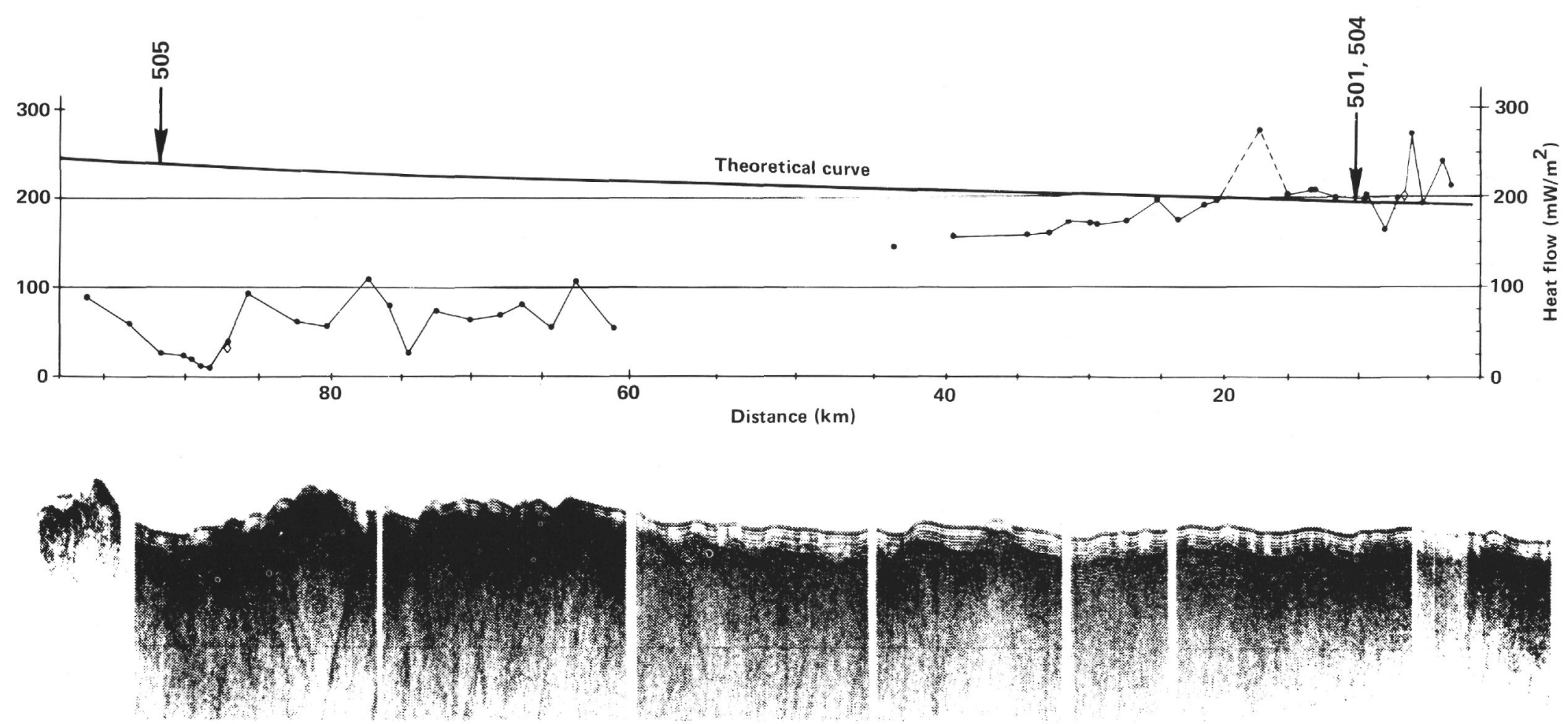

Figure 3. Site survey surface heat flow measurements and seismic profile on the southern flank of the Costa Rica Rift, after Langseth et al., 1983, and Hobart et al. (this volume). The spreading axis is about $110 \mathrm{~km}$ farther north (left) than this figure shows. Several holes, including Hole 504B, were drilled in the vicinity of Sites 501 and 504 (Cann, Langseth, Honnorez, Von Herzen, White, et al., 1983). 
Table 1. Temperature logs during the four DSDP legs in Hole 504B.

\begin{tabular}{|c|c|c|c|c|}
\hline & Date & Tool & $\begin{array}{l}\text { Hole depth } \\
\text { (m) }\end{array}$ & Hole condition \\
\hline \multirow[t]{3}{*}{$\begin{array}{l}\text { Leg } 69 \\
(1979)\end{array}$} & 14 October & T-probe & to 220 & $\begin{array}{l}\text { Hole } 504 \mathrm{C} \text { sediment temperatures at } 4 \text { depths, } \approx 60 \mathrm{~m} \text { from } \\
\text { Hole } 504 \mathrm{~B}\end{array}$ \\
\hline & 22 October & GO-DT & 489 & $34 \mathrm{hr}$ after drilling and circulation ceased \\
\hline & 24 October & GO-DT & 489 & $70 \mathrm{hr}$ after drilling and circulation ceased \\
\hline & 3 December & T-probe & 489 & 43 days after Leg 69 drilling and circulation ceased \\
\hline \multirow{3}{*}{ (1979) } & 8 December & T-probe & 656 & $30 \mathrm{hr}$ after drilling and circulation ceased \\
\hline & 14 December & GO-DT & 836 & $40 \mathrm{hr}$ after drilling and circulation ceased \\
\hline & 16 December & GO-DT & 836 & $75 \mathrm{hr}$ after drilling and circulation ceased \\
\hline \multirow[t]{4}{*}{$\begin{array}{l}\text { Leg } 83 \\
(1981)\end{array}$} & 23 November & T-probe & 836 & $\begin{array}{l}23 \text { months (707 days) after Leg } 70 \text { drilling and circulation } \\
\text { ceased }\end{array}$ \\
\hline & 16 December & S-HRT & 1287.5 & $5 \mathrm{hr}$ after circulation ceased \\
\hline & 20 December & S-HRT & 1287.5 & $58 \mathrm{hr}$ after circulation ceased \\
\hline & 21 December & S-HRT & 1287.5 & $82 \mathrm{hr}$ after circulation ceased \\
\hline $\begin{array}{l}\text { Leg } 92 \\
(1983)\end{array}$ & 8 April & $\begin{array}{l}\text { T-probe } \\
\text { and HPC } \\
\text { tool }\end{array}$ & 1350 & $\begin{array}{l}15 \text { months ( } 462 \text { days) after Leg } 92 \text { drilling and circulation } \\
\text { ceased }\end{array}$ \\
\hline
\end{tabular}

Note: Data discussed in this chapter are indicated either with an asterisk (equilibrium temperature measurements) or brackets (paired temperature logs allowing extrapolations to equilibrium). The GO-DT logs of 22 and 24 October 1979 and 8 December 1979 are discussed in Becker, Langseth, and Von Herzen (1983). The 16 December 1981 S-HRT was run solely to check borehole temperatures before deploying the temperature-sensitive borehole televiewer.

Table 2. Temperature-logging tools used in Hole 504B.

\begin{tabular}{|c|c|c|c|c|}
\hline Tool & $\begin{array}{l}\text { DSDP } \\
\text { T-probe }\end{array}$ & $\begin{array}{c}\text { Gearhart-Owen } \\
\text { DT }\end{array}$ & $\begin{array}{c}\text { Schlumberger } \\
\text { HRT }\end{array}$ & $\begin{array}{l}\text { Von Herzen } \\
\text { HPC tool }\end{array}$ \\
\hline Legs & $69,70,83,92$ & 69,70 & 83 & 92 \\
\hline Sensor & Thermistor & Thermistor & Nickel wire & Thermistor \\
\hline Housing & Stainless steel & Steel & Teflon tube & 14.35-mm-thick cylindrical \\
\hline Diameter in $\mathrm{mm}$ & 12.5 & $\approx 3$ & $\approx 2$ & iron HPC cutting shoe \\
\hline Time constant ${ }^{\mathrm{a}}(\mathrm{s})$ & $120-180$ & $<30$ & $<30$ & \\
\hline $\begin{array}{l}\text { Temperature } \\
\text { calibration }\end{array}$ & $0-100^{\circ} \mathrm{C}$ water bath & $\begin{array}{l}\text { Ocean bottom } \\
\text { water reading }\end{array}$ & $\begin{array}{l}\text { Shipboard water ice } \\
\text { and boiling checks }\end{array}$ & $0-100^{\circ} \mathrm{C}$ water bath \\
\hline $\begin{array}{l}\text { Range of } \\
\text { temperatures } \\
\text { measured }\left({ }^{\circ} \mathrm{C}\right)\end{array}$ & $\begin{array}{l}2-103 \\
\quad(2-144 \text { during Leg } 92)\end{array}$ & $2-110$ & $2-135$ & $2-70$ \\
\hline $\begin{array}{l}\text { Estimated accuracy } \\
\text { of temperatures } \\
\left({ }^{\circ} \mathrm{C}\right)\end{array}$ & $\begin{array}{l} \pm 0.1 \\
\quad(? \pm 5 \text { above } 100)\end{array}$ & \pm 1 & \pm 2 & \pm 0.05 \\
\hline $\begin{array}{l}\text { Estimated accuracy } \\
\text { of depths }(\mathrm{m})\end{array}$ & \pm 2 & \pm 5 & \pm 1 & \pm 2 \\
\hline
\end{tabular}

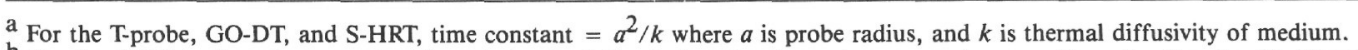

$\mathrm{b}$ For the HPC tool, a time constant is not simply defined, but the thermal response is as rapid as the T-probe (K. Horai, unpublished manuscript).

$504 \mathrm{C}$, it was immediately clear that an unusual, transient, thermal process was dominant. In every case, the Hole 504B temperatures to a depth of about 350-370 m were strongly depressed relative to the sediment temperatures (Fig. 4). From this we deduced early that ocean bottom water must have been flowing down into the hole at a rate of several thousands of liters per hour. Since the temperatures sharply increased below $370 \mathrm{~m}$, this flow must have been diverted into a permeable formation in the upper $\sim 100 \mathrm{~m}$ of basement, between the bottom of the casing $(275 \mathrm{~m})$ and $370 \mathrm{~m}$.

During Legs 70, 83, and 92, the first activities after reentry of Hole 504B were DSDP T-probe/water sampling measurements. These represented the best assessment of thermal conditions recovered from the drilling disturbances of the previous legs, and thus isolated the effect of the downhole flow. The Leg 70 reentry measurements were made long enough after Leg 69 that the thermal disturbance to the hole caused by Leg 69 operations should have decayed to within $1-2 \%$ of its peak value (Bullard, 1947; Jaeger, 1961). These measurements were treated as equilibrium values, fully recovered from the drilling disturbance. Since Leg 83 reentered Hole 504B over 23 months after Leg 70, the hole and surrounding crust should have been fully equilibrated from the Leg 69 and 70 disturbances. Similarly, since Leg 92 reentered Hole 504B over 15 months after Leg 83, the hole and crust should have been fully equilibrated from the Leg 83 disturbance. The Leg 83 reentry measurements showed that there was still strong flow of bottom water into the upper $\sim 100 \mathrm{~m}$ of basement (Fig. 4) more than two years after the hole was drilled. However, while the Leg 83 temperatures were still strongly depressed to about $350 \mathrm{~m}$, they were somewhat higher than the Leg 70 values, indicating that the downhole flow had slowed during this interval. The decay of the downhole flow rate was dramatically confirmed by the Leg 92 temperatures to about $350 \mathrm{~m}$ (Fig. 4), which were considerably warmer than the Leg 83 values, yet still depressed relative to the Hole $504 \mathrm{C}$ sediment temperatures. 

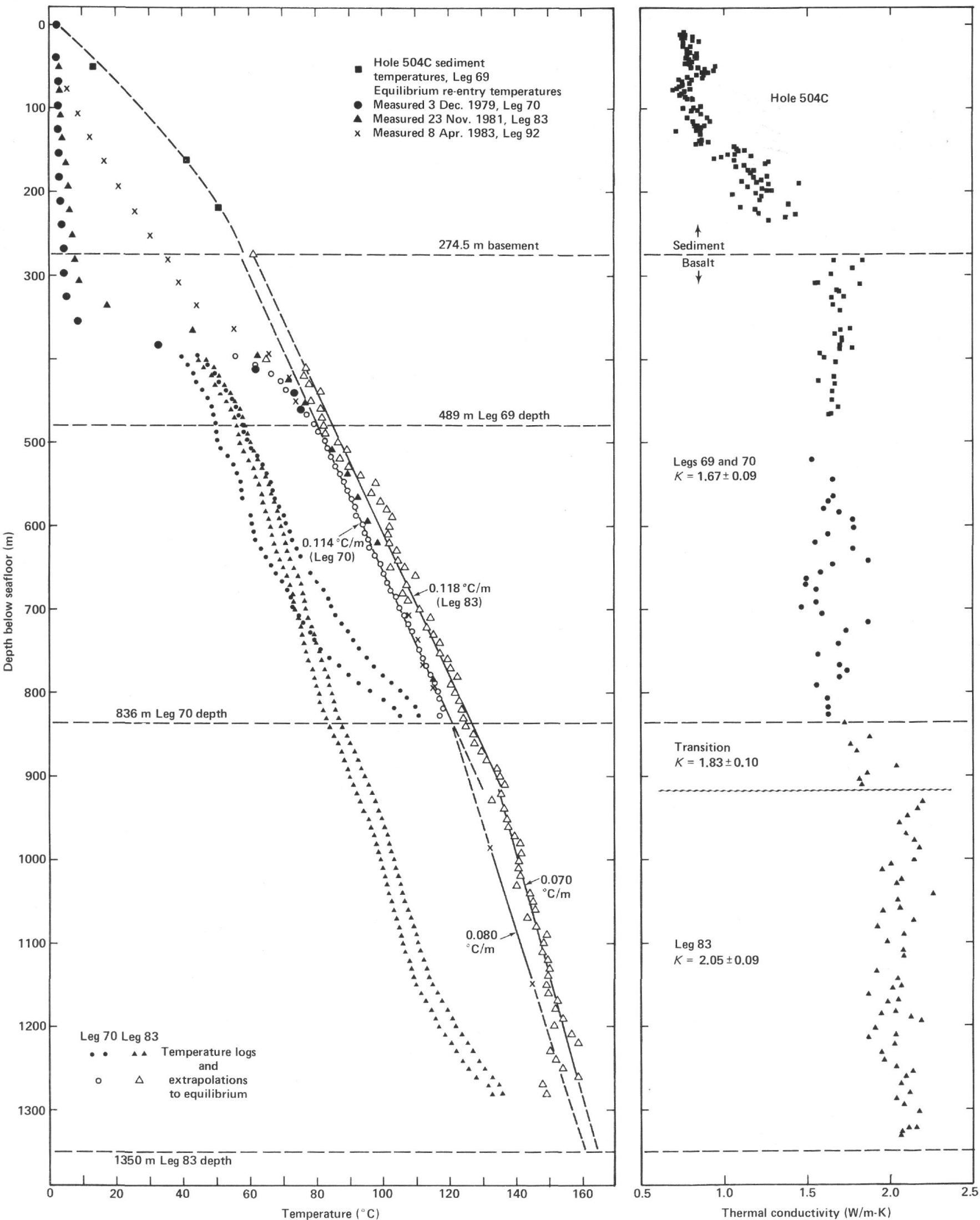

Figure 4. Temperature and thermal conductivity measurements throughout Hole 504B. The paired temperature logs were extrapolated to equilibrium using the method of Bullard (1947). Sediment thermal conductivity values are from Hole 504 (Wilkens and Langseth, 1983); Legs 69 and 70 basalt values are from Karato et al. (1983). 
The indication from temperature measurements of flow of ocean bottom water into the uppermost basement was verified by analyses of water samples from borehole (Mottl et al., 1983; Mottl, this volume). It was also consistent with the results of Anderson and Zoback (1982), who measured during Leg 69 an in situ pore water underpressure of $\sim 0.8 \mathrm{MPa}$ ( 8 bars) relative to hydrostatic pressure in the uppermost $200 \mathrm{~m}$ of basement. Thus, the downhole flow was not thermal, buoyancy convection, but was motion forced by the pressure differential between ocean bottom water and basement pore fluids.

Toward the end of Leg 70, after drilling and circulation were stopped, a pair of GO-DT logs was run, $35 \mathrm{hr}$ apart, to the Leg 70 hole depth of $836 \mathrm{~m}$. Similarly, after the major phase of Leg 83 drilling, a pair of S-HRT logs was run, $24 \mathrm{hr}$. apart, to a depth of $1287.5 \mathrm{~m}$. In each case special care was taken to avoid disturbing the hole between the two logs. They could thus be extrapolated for an assessment of equilibrium geothermal conditions in the deep basement section, which was unaffected by the flow of water in the upper $\sim 370 \mathrm{~m}$ of the hole.

In the following sections, we assess the geothermal data in terms of both an accurate determination of the heat transfer at Site 504 and a reliable estimate of the water flow rate down the hole. The equilibrium heat flow in the sediments is a boundary and initial condition for the problem of downhole flow through the casing. Two methods are used to estimate upper bounds on the timevarying downhole flow rate based on the Leg 70, 83, and 92 reentry temperature measurements in the cased section of the hole. We can then estimate the permeability of the underpressured reservoir into which the downhole flow is directed. Finally, we consider the deeper temperature and thermal conductivity measurements in detail to determine the heat flow through the $1 \mathrm{~km}$ of oceanic basement cored in Hole 504B.

\section{GEOTHERMAL MEASUREMENTS IN THE SEDIMENTS AT SITE 504}

Detailed discussions of site survey surface heat flow measurements and sediment temperatures in Holes 501, 504A, and 504C are given by Langseth et al. (1983) and Hobart et al. (this volume). Near Hole 504B, surface heat flows are quite uniform at about $200 \mathrm{~mW} / \mathrm{m}^{2}$ (Fig. 3), in agreement with the $195-205 \mathrm{~mW} / \mathrm{m}^{2}$ predicted for conductively cooling 5.9-m.y.-old ocean crust (e.g., Parsons and Sclater, 1977; Lister, 1977). Sediment temperatures measured in Holes 501, 504A, and 504C are also consistent with this heat flow value. In Hole 504C, offset only about $60 \mathrm{~m}$ from Hole 504B, sediment temperatures are reasonably linear with integrated thermal resistance, indicating a dominantly conductive heat flow of $196 \mathrm{~mW} /$ $\mathrm{m}^{2}$. An important implication of these measurements is that $274.5 \mathrm{~m}$ of sediment cover forms an impenetrable barrier to hydrothermal fluid exchange between the basement and bottom water. Thus, before Hole 504B was drilled, a conductive temperature gradient must have existed down to the sediment/basement contact. Extrapolation of the conductive heat flow temperature profile through the $274.5 \mathrm{~m}$ of sediment yields an equilibrium temperature of $58-59^{\circ} \mathrm{C}$ at this contact.

\section{CALCULATION OF RATE OF WATER FLOW DOWN HOLE 504B}

Given the accurately determined heat flow in the surrounding sediments, the downhole flow rate can be obtained from the temperatures in the cased section of the hole. The flow rate of course must remain uniform with depth through the casing, which acts as a pipe bypassing the sediment. For each of the Leg 70, 83, and 92 reentry temperature data sets, we obtained two consistent estimates of the flow rate, using two different models of the thermal balance in the borehole. For each of these models we assumed that the flow rate was constant with time, as well as with depth. We assumed that the downhole flow started when Leg 69 drilled into the upper $\sim 100 \mathrm{~m}$ of basement, about 50,772 , and 1272 days before the Leg 70, 83, and 92 measurements, respectively. We also assumed that the seawater in the borehole was well mixed so that temperatures were radially uniform, an assumption later justified by the magnitudes of the flow rates.

In the first model (Becker, Langseth, and Von Herzen, 1983, eqs. 2-7) a quasi-steady-state thermal balance gives an explicit, but approximate solution for the flow rate in terms of the undisturbed geothermal gradient and the temperatures measured in the casing. This model yielded $88 \mathrm{~m} / \mathrm{hr}$. $(24.5 \mathrm{~mm} / \mathrm{s})$ for the Leg 70 data, $23 \mathrm{~m} /$ hr. $(6.5 \mathrm{~mm} / \mathrm{s})$ for the Leg 83 data, and $1.7 \mathrm{~m} / \mathrm{hr}$. $(0.5$ $\mathrm{mm} / \mathrm{s}$ ) for the Leg 92 data.

In the second model, we solved a more complete, fully transient formulation of the thermal balance in the borehole, in a semi-infinite geometry with prescribed initial values, after Lesem et al. (1957). (See, also, appendix of Becker, Langseth, and Von Herzen, 1983.) The borehole temperature is obtained by numerical integration of a complicated inverse Laplace Transform; there is no explicit method of inverting for the flow rate, but it can be obtained with reasonable precision by fitting measured temperatures to the theoretical temperaturedepth profiles. The Leg 70,83 , and 92 reentry temperatures in the cased section of the hole and theoretical profiles are plotted in Figure 5A-C. In each case, the misfit is worse in the upper part of the cased section, where the temperatures only poorly resolve the flow rate. Aside from this, the measured borehole temperatures fit the profiles for $90 \mathrm{~m} / \mathrm{hr}$. $(25.0 \mathrm{~mm} / \mathrm{s})$ at 50 days $(\operatorname{Leg} 70)$, $25 \mathrm{~m} / \mathrm{hr}$. $(6.9 \mathrm{~mm} / \mathrm{s})$ at 772 days (Leg 83), and $2.4 \mathrm{~m} / \mathrm{hr}$. $(0.7 \mathrm{~mm} / \mathrm{s})$ at 1272 days (Leg 92).

Based on a subjective assessment of the misfit of our data to the theoretical profiles and a consideration of the uncertainties in the many parameter values that entered into the calculations, we adopted estimates of the time-averaged flow rates of $90 \pm 10 \mathrm{~m} / \mathrm{hr}$. $(25 \pm 3 \mathrm{~mm} /$ s) at 50 days, $25 \pm 5 \mathrm{~m} / \mathrm{hr}$. $(7 \pm 1 \mathrm{~mm} / \mathrm{s})$ at 772 days, and $2.4 \pm 0.5 \mathrm{~m} / \mathrm{hr}$. $(0.7 \pm 0.1 \mathrm{~mm} / \mathrm{s})$ at 1272 days. These are equivalent to volume fluxes of $6360 \mathrm{~L} / \mathrm{hr}$. at 50 days, $1770 \mathrm{~L} / \mathrm{hr}$. at 772 days, and $170 \mathrm{~L} / \mathrm{hr}$. at 1272 days. The Reynolds numbers for these flows are given by $\operatorname{Re}=2 a v / \nu$, where $v$ is the flow rate, $a$ is the casing 
A

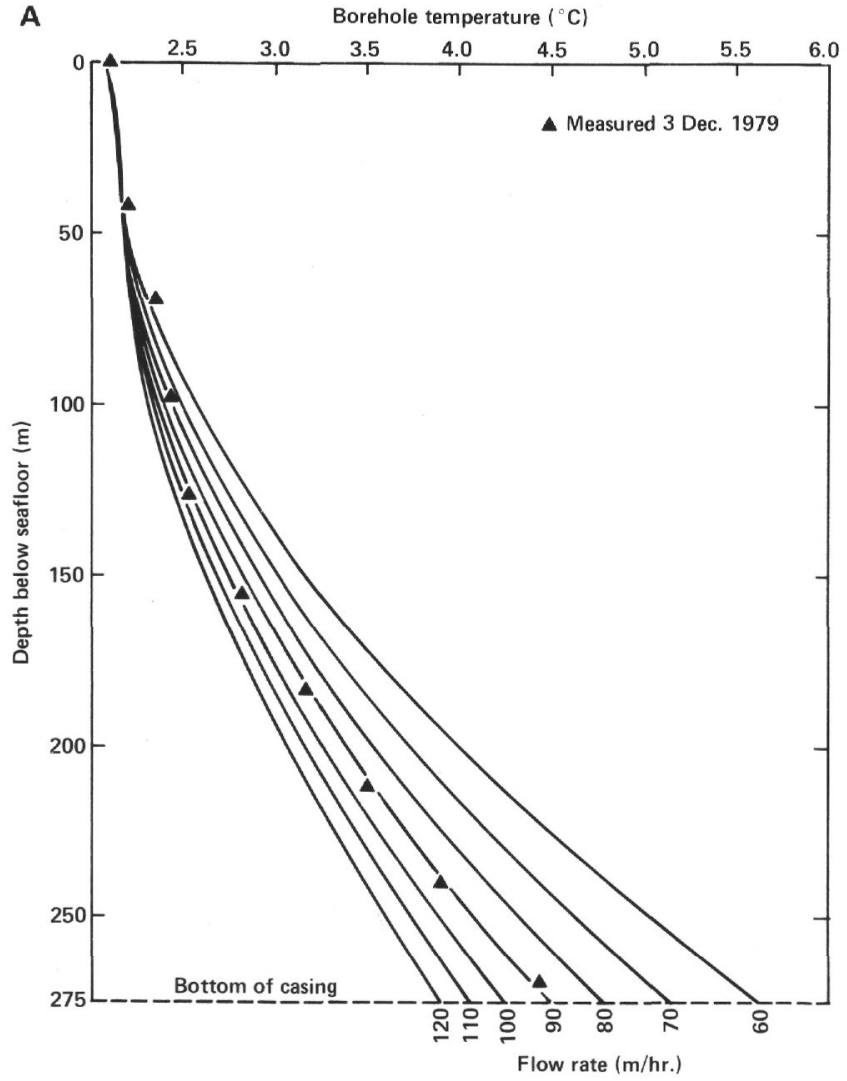

B

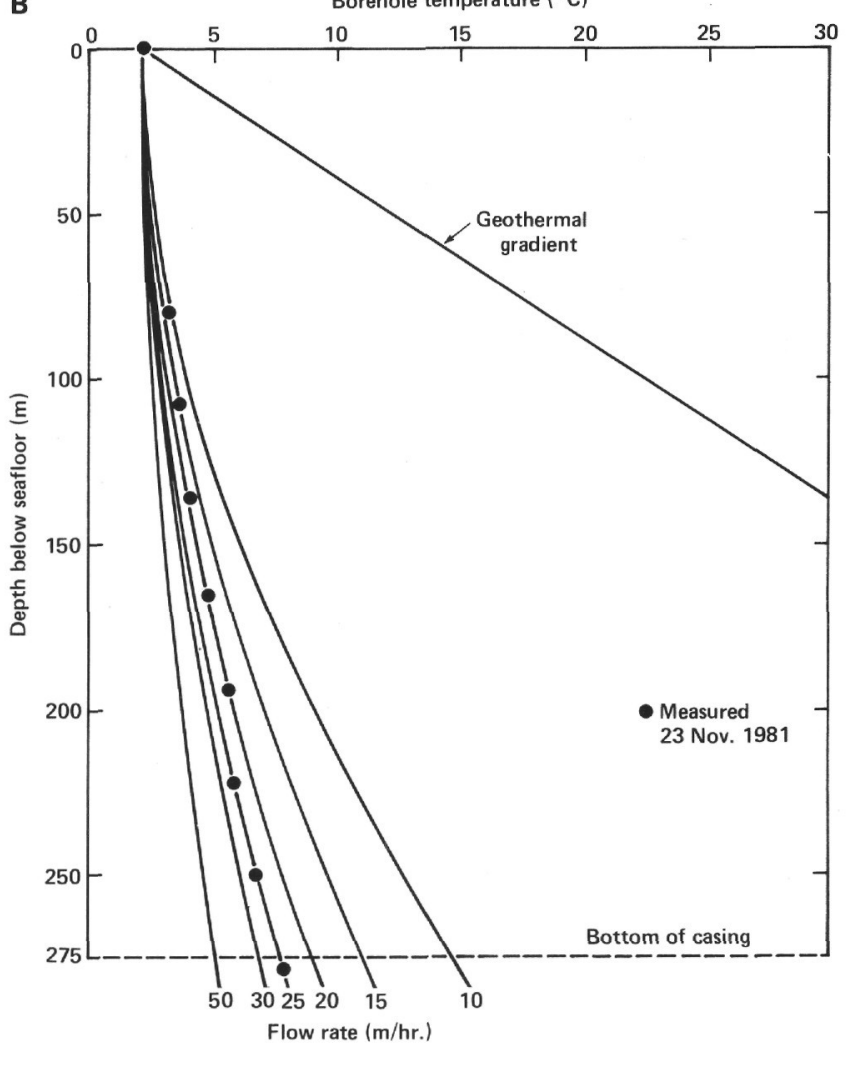

C

C Borehole temperature $\left({ }^{\circ} \mathrm{C}\right)$

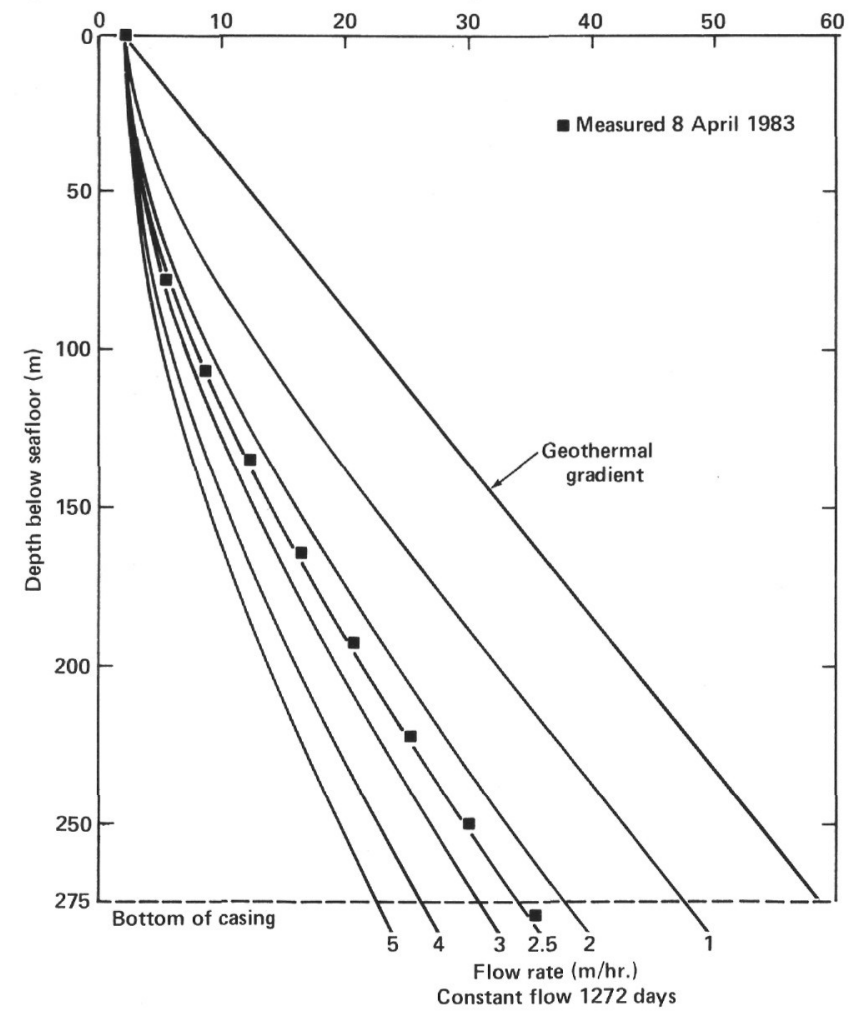

Figure 5. A. Leg 70 reentry temperatures through casing, along with predicted profiles for constant flow rates since the downhole flow started during Leg 69. B. Same for Leg 83 reentry temperatures, over two years after the downhole flow started during Leg 69 . The geothermal gradient is the average gradient measured in the sediments at Hole $504 \mathrm{C}, 0.205^{\circ} \mathrm{C} / \mathrm{m}$. C. Same for Leg 92 reentry temperatures, nearly three and a half years after the downhole flow started during Leg 69. 
radius $(0.15 \mathrm{~m})$, and $\nu$ is the kinematic viscosity of seawater $\left(\sim 1.6 \mathrm{~mm}^{2} / \mathrm{s}\right.$ at $2-5^{\circ} \mathrm{C}$; Defant, 1961, p. 50$)$. The Reynolds numbers were on the order of 4700 at 50 days, 1300 at 772 days, and 130 at 1272 days. Since the critical Reynolds number for flow in a pipe is about 2300 (Reynolds, 1883; Schlichting, 1968, ch. 16), the downhole flow was transitionally turbulent over most of the two years between Legs 69 and 83. This probably justifies our assumption of radial uniformity of the borehole temperature.

Clearly, a significant reduction in the downhole flow occurred in the three and a half years between Legs 69 and 92. Therefore, our constant flow rate models do not fully describe the flow, but we have not yet expanded these models to include a time-decaying rate. The constant rate models probably overestimate the real rate at a given time, and our estimates should be taken as firstorder upper bounds. The decay of these first-order estimates of flow rate with time is only poorly described by simple relationships (linear, exponential, or power-law) of flow rate and time. The initial flow rate, when Leg 69 first punctured the sediment seal, was probably on the order of $100 \mathrm{~m} / \mathrm{hr}$. (7000 L/hr.), and a total of about 50 $\times 10^{6} \mathrm{~L}$ of seawater was drawn into the formation during the two years between Legs 69 and 83. The downhole flow probably continued at a decaying rate and may well have ceased within a year or so after Leg 92 .

\section{THE UNDERPRESSURED BASEMENT RESERVOIR}

The destination of the water flow down Hole 504B can be determined by careful examination of the equilibrium reentry temperatures deeper than the casing. Figure 6 shows these reentry measurements along with predicted values for constant flow down the hole. In each case, at nearly $100 \mathrm{~m}$ into basement, the measured temperatures sharply increase toward the values expected by downward continuation of the conductive heat flux in the sediments. This can only occur if the downward flow has all but stopped, and the water flowing downhole has been directed radially into the basement above $\sim 370 \mathrm{~m}$.

Two other observations are important: first, in each of the Leg 70 and 83 profiles, the two temperature samples $\leq 30-50 \mathrm{~m}$ below the casing lie directly on the predicted curve, and second, the Leg 83 temperatures increase toward the original formation temperatures about $20 \mathrm{~m}$ shallower than observed on Leg 70 . This depth difference was also apparent in the other temperature logs with independent depth resolution, so it is not due to an error in depth measurement. (These effects are not apparent in the Leg 92 data, partly because the Leg 92 temperatures were considerably closer to the geothermal gradient, and partly because of a slight but suspicious offset in the Leg 92 data immediately below the casing.) After Leg 70, Becker, Langseth, and Von Herzen (1983) initially interpreted the first effect to indicate that no significant amount of the downhole flow was directed into basement shallower than $\sim 330 \mathrm{~m}$, and they modeled the situation with a thin $(30 \mathrm{~m})$ reservoir within the basement, at about 330-360 m. In light of the Leg 83

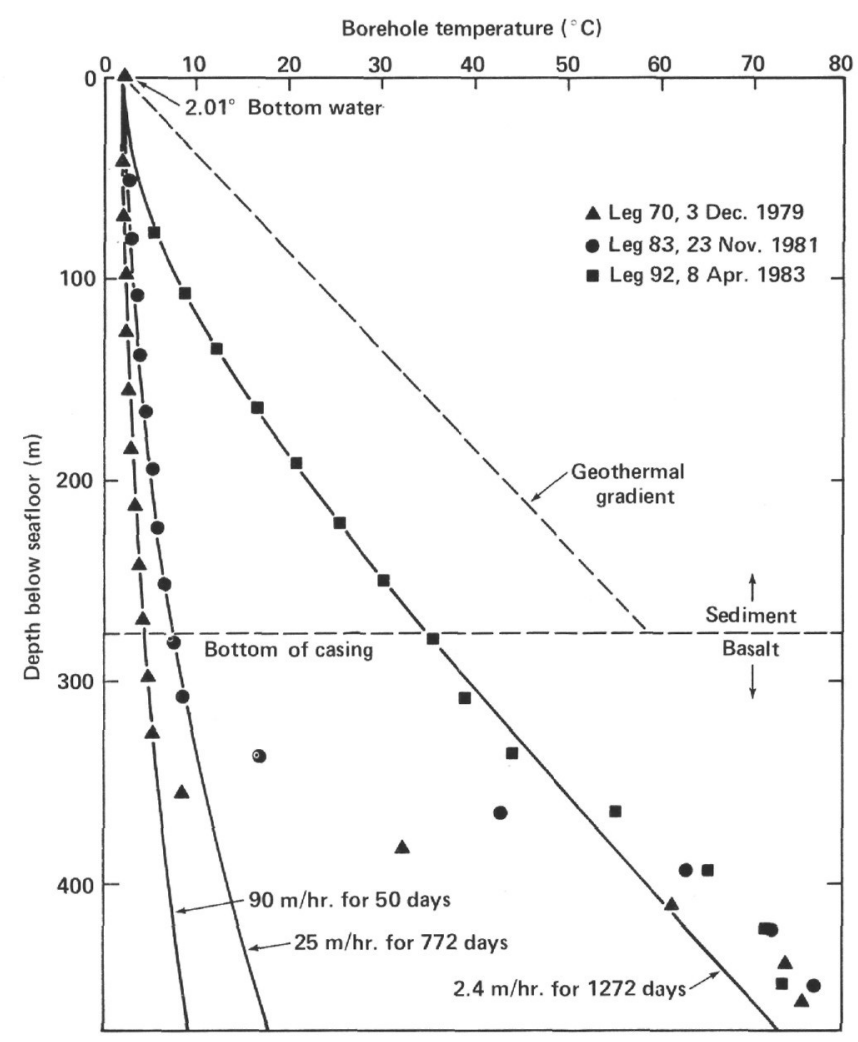

Figure 6. Leg 70, 83, and 92 equilibrium reentry temperatures and best-fit theoretical profiles for constant flow rates. The sharp increase in temperatures at about $350-370 \mathrm{~m}$ indicates that virtually no flow continued deeper.

results, particularly the upward migration with time of the depth of temperature increase, we now consider it likely that the reservoir encompasses the uppermost $\sim 100 \mathrm{~m}$ of basement. Also, we reason that the borehole temperatures will noticeably increase toward the formation temperatures only at a depth below which the downhole water flux drops below a certain threshold rate. Therefore, nearly isothermal conditions above this depth do not necessarily indicate that none of the water is drawn into the formation above. In other words, some of the downhole flow may have been diverted into the upper part of the reservoir without significantly affecting the depressed borehole temperatures; the temperature measurements could not then resolve the upper boundary of the reservoir.

If the depth of temperature increase was shallower on Leg 83, it may have been slightly deeper when the downhole flow started on Leg 69 than indicated by the Leg 70 temperatures (Fig. 6). Thus we model the reservoir as being very nearly $100 \mathrm{~m}$ thick. This corresponds well to a layer of high apparent porosity revealed by the largescale electrical resistivity experiment of Becker et al. (1982) and Becker (this volume) from which we reproduce Figure 7. This high porosity layer/aquifer has been tentatively identified with Layer $2 \mathrm{~A}$ by Becker et al. (1982) and Anderson, Honnorez, et al. (1982), although it is probably too thin to be resolved in the existing seismic data (e.g., Stephen, 1983; Stephen and Harding, 1983; Little and Stephen, this volume). 


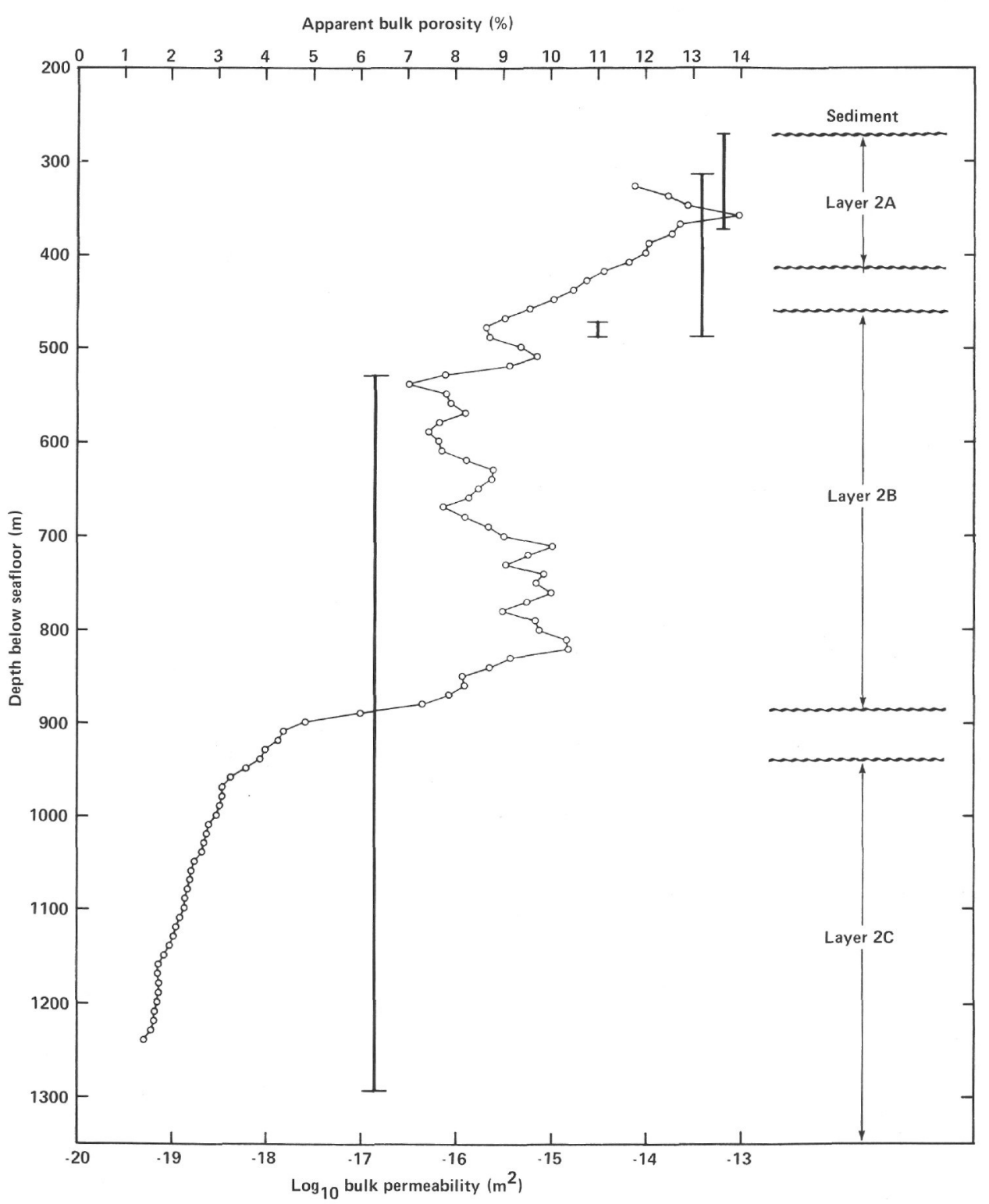

Figure 7. Apparent bulk porosities (circles) and bulk permeabilities (vertical bars) of basement in Hole 504B. After Becker et al. (1982). Anderson and Zoback (1982), Anderson, Zoback, et al. (this volume).

By Darcy's law, the extent of the reservoir must result from some combination of local permeability contrasts and/or locally maintained pressure gradients. We prefer the former possibility, based primarily on the results of Anderson and Zoback (1982), who found formation fluid underpressures of about $0.8 \mathrm{MPa}(8 \mathrm{bars})$ in the basement at $474-489 \mathrm{~m}$, some $100 \mathrm{~m}$ deeper than the downhole flow extends. We assumed that the initial basement underpressures held uniformly in the upper $200 \mathrm{~m}$ of basement and that the water flow down the hole was diverted into an anomalously permeable formation. We then developed a radially infinite reservoir model that allowed us to estimate the permeability of the formation (Becker, Langseth, and Von Herzen, 1983, eqs. 8-11).

In this model, by coupling a radial pressure diffusion equation with Darcy's law, we obtained an explicit relationship of permeability with the flow rate, original base- ment underpressure, and thickness of the reservoir. Taking the measured basement underpressure of Anderson and Zoback (1982), along with an initial volume flux of $6000-7000 \mathrm{~L} / \mathrm{hr}$ and a reservoir thickness of $\sim 100 \mathrm{~m}$, we estimate a permeability of about $6 \pm 1 \times 10^{-14} \mathrm{~m}^{2}$ ( 0.06 darcy) for the reservoir. The permeability value is most sensitive to, and varies inversely with, reservoir thickness. Becker, Langseth, and Von Herzen (1983) originally obtained $20 \times 10^{-14} \mathrm{~m}^{2}$ for a reservoir $30 \mathrm{~m}$ thick. The value of $6 \times 10^{-14} \mathrm{~m}^{2}$ is then a lower bound for the permeability of the reservoir if it is somewhat thinner than $100 \mathrm{~m}$. This permeability value is quite consistent with three other direct measurements of lower bulk permeability deeper in the hole (Fig. 7) (Anderson and Zoback, 1982; Anderson, Zoback, et al., this volume). The decrease of measured permeability with depth in Hole 504B is much stronger than in previous models 
for the oceanic crust (Anderson, Zoback, et al., this volume).

The infinite reservoir model also predicted that the flow rate at the time of the Leg 83 reentry would be on the order of $80 \mathrm{~m} / \mathrm{hr}$, much greater than the $25 \mathrm{~m} / \mathrm{hr}$ estimated from Leg 83 temperatures. The strong decrease in flow rate over the three and a half years between Legs 70 and 92 may indicate that the underpressure of basement pore fluids may have been significantly reduced by the cumulative water flux into the formation. In addition, it is possible that the permeability of the formation may have been reduced as a result of the influx of cold water, possibly by precipitation and partial sealing of fracture porosity, although the apparent porosities of Becker (this volume) show no indication of this (Fig. 7). On the other hand, the mismatch of the Leg 83 flowrate estimate with that predicted by the infinite reservoir model may also indicate that the reservoir model is inadequate and that the real reservoir may have a more limited lateral extent.

\section{BASEMENT HEAT FLOW}

\section{Deep Borehole Temperatures in Hole 504B}

The two GO-DT temperature logs run at the end of Leg 70 were taken about 40 and $75 \mathrm{hr}$. after the cessation of drilling and circulation in the hole. Similarly, the two S-HRT temperature logs on Leg 83 were run 58 and 82 hr. after both major phase of Leg 83 drilling (to 1287.5 $\mathrm{m}$ ) and some short periods of circulation to cool the hole for specific temperature-sensitive tools. For each of these pairs of temperature logs, the measurements were made sufficiently long after circulation and sufficiently long apart so that they could be reasonably treated by the theories for the return of a borehole to equilibrium formation temperature. Hyndman et al. $(1976,1977)$ gave a detailed comparison of the several available theories; Becker, Langseth, and Von Herzen (1983) briefly reviewed the three best possibilities with regard to the measurements in Hole 504B.

Hyndman et al. $(1976,1977)$ preferred the solution of Jaeger $(1956,1961)$ for the temperature decay after the hole is held at a constant temperature for a time corresponding to the drilling disturbance time. This is potentially the most accurate method, particularly when it is modified to accommodate both a depth variation of temperature and discontinuous drilling (Burch and Langseth, 1981). However, this method requires a detailed knowledge of several parameters, particularly the circulation rate during drilling. Since the total circulation rate in Hole 504B was some undetermined combination of forced pumping from the ship and the pressure-driven flow of bottom water into the upper basement, the parameters needed to apply this potentially more accurate theory were not fully determined.

For this reason and because of its simplicity, we originally applied Bullard's (1947) theory to extrapolate our two pairs of temperature logs to equilibrium. Bullard (1947) modeled the thermal disturbance to a borehole from drilling and circulation as a line source of heat; he represented the end of the disturbance with a negative source of the same strength. The borehole temperature could then be obtained as a simple function of four parameters: (1) the duration of the disturbance, (2) the time after the disturbance, (3) the source strength, and (4) the thermal conductivity of the surrounding crust. With two temperature logs at two different times, only the duration of the disturbance and the times of the measurements need be known for an extrapolation to equilibrium temperatures. Lachenbruch and Brewer (1959) obtained excellent results with this theory, and gave a complete discussion of the possible errors involved. (See also Jaeger, 1965, p. 17.)

The formulation could easily be modified to handle the intermittent nature of the drilling and circulation disturbance to the hole (Becker, Langseth, and Von Herzen 1983). For each of the two pairs of temperature logs, a simplified version of the prior, intermittent drilling and circulation history was applied. We considered only pauses in drilling as short as the time required to change bits, on the order of one day. During Leg 70 three bits were used, so three periods of drilling were applied to the Leg 70 data. During Leg 83, six bits were used in coring to $1287.5 \mathrm{~m}$, and two major pauses in drilling, each on the order of three days, occurred when the pipe broke twice. In addition to these pauses, short periods of circulation during the Leg 83 logging program were accounted for. Of course, since the hole depth varied at the times of these disturbances, different sections of the hole were subject to different histories of disturbance.

The temperature logs were sampled for these extrapolations at $10-\mathrm{m}$ intervals, and the results are plotted in Figure 4, along with the equilibrium reentry temperature profiles. Also shown are best-fit gradients through the extrapolated temperatures obtained by linear regression. The Leg 70 extrapolations very closely fit a gradient of $0.114^{\circ} \mathrm{C} / \mathrm{m}$. In the same section of basement. $400-836 \mathrm{~m}$, the Leg 83 extrapolations are about $5^{\circ} \mathrm{C}$ higher than the Leg 70 values, but fit a very similar gradient, $0.118^{\circ} \mathrm{C} / \mathrm{m}$. We attribute the $5^{\circ}$ offset in results from the two legs to some combination of measurement imprecision, particularly with the Leg 83 S-HRT, and possible inaccuracies resulting from oversimplifications in the extrapolation method, particularly with respect to the more complicated Leg 83 drilling and circulation history. The important results are the linearity of the apparent temperature gradient and the good agreement in its value. The Leg 83 and 92 reentry equilibrium temperatures between 500 and $800 \mathrm{~m}$ lie immediately between the two extrapolations or directly on the Leg 70 extrapolation, confirming the value of the gradient, and suggesting an accuracy for the Leg 70 extrapolations on the order of $\pm 2-3^{\circ} \mathrm{C}$. This also suggests that the Leg $83 \mathrm{ex}-$ trapolations may be up to $5^{\circ}$ too high, as mentioned above, whereas the Leg 83 apparent gradient agrees with the Leg 70 gradient. When the apparent gradients are themselves extrapolated back to the sediment/basement interface they indicate temperatures of $57-61{ }^{\circ} \mathrm{C}$, in good agreement with the $58-59^{\circ} \mathrm{C}$ obtained from sediment temperatures in Hole 504C.

Deeper than $900 \mathrm{~m}$, which marks the transition from pillow lavas to sheeted dikes and massive units (Anderson, Honnorez, et al., 1982), the Leg 83 extrapolated 
temperatures show a distinct break in the apparent gradient. This change corresponds directly to a steplike $\sim 25 \%$ increase in sample thermal conductivities (Fig. 4). The two imprecise Leg 92 minimum temperature values below $900 \mathrm{~m}$ confirm the change in the gradient at the transition and are consistent with the Leg 70 gradient shallower than $900 \mathrm{~m}$. The Leg 83 and 92 gradients extrapolate to an estimated equilibrium bottom-hole (1350 m) temperature of $160-165^{\circ} \mathrm{C}$.

\section{In Situ Thermal Conductivity and Conductive Heat Flow}

In order to estimate the conductive heat flow through the full $1 \mathrm{~km}$ of basement cored in Hole 504B, we attempted to correct the shipboard measurements of sample thermal conductivities to in situ conditions. Corrections for temperature and pressure are standard for measurements on marine sediments (Ratcliff, 1960), but have not been reliably established for oceanic basalts. (Generally, small corrections for crustal pressures are reported, but contradictory data exist regarding possibly large temperature corrections for the high temperatures in Hole 504B. For example, the factors reported by Hyndman and Drury [1976], based on the high pressure, dry basalt data of Schloessin and Dvorak [1977], +0.34 $\mathrm{mW} \mathrm{m} \mathrm{m}^{-1} \mathrm{~K}^{-1} \mathrm{MPa}^{-1}$ and $-5.4 \mathrm{~mW} \mathrm{~m}^{-1} \mathrm{~K}^{-2}$, would produce a negligible pressure correction to our sample measurements, but an unreasonable negative temperature correction of $25 \%$.) However, we did attempt to correct for the bulk porosity of the section and the temperature and pressure dependence of the conductivity of the pore fluid. The salinities of the sampled pore fluids were very close to that of seawater (Mottl et al., 1983; Mottl, this volume). Therefore the thermal conductivity of the pore fluid was taken to be that of seawater, which was estimated to be $4 \%$ lower (Defant, 1961, p. 50) than that of pure water at appropriate temperature and pressure, after Clark (1966, p. 482).

The bulk conductivity of the basement was then estimated, using the apparent bulk porosities (Fig. 7) determined from the large-scale electrical resistivity experiment in Hole 504B (Becker et al., 1982). Several relationships exist for determining the bulk conductivity of a porous matrix (e.g., Robertson and Peck, 1974); we used the exponential relationship of Woodside and Messmer (1961), as applied by Sass et al. (1971):

$$
K_{\text {bulk }}=K_{\text {basalt }}^{\left(1-\phi_{f}\right)} K_{\text {seawater }}^{\phi_{f}}
$$

with $\phi_{f}$ being the fracture porosity of the section. The measured sample basalt conductivity is itself a function of the sample grain porosity, so the fracture porosity $\phi_{f}$ was estimated by the difference between the apparent bulk porosities of Becker et al. (1982) and the average sample grain porosities of Karato et al. (1983) and Kinoshita (in Hole 504B summary chapter, this volume).

The sample basalt conductivities fall nicely into two separate layers, each with a closely determined mean value (Fig 4). Moreover, these layers correspond well to the layering in apparent bulk porosities (Fig. 7). Therefore a simple two-layer conductivity structure was carried through the entire correction procedure. Indeed, the slope change in the apparent basement temperature gradient of Figure 4 argues for a two-layer in situ conductivity structure.

The results of this correction procedure and our estimates of in situ conductive heat flow are summarized in Table 3. Note that within estimated errors the heat flow estimates in the sediment and in the upper section of basement agree reasonably well and are close to the predicted plate heat transfer of 195-205 $\mathrm{mW} / \mathrm{m}^{2}$ (Parsons and Sclater, 1977; Lister, 1977). To the contrary, the heat flow estimates for the deeper basement section are somewhat lower, but with considerable possibility for errors. If real, this is a puzzling reduction of heat flow with depth, particularly considering that the heat flow in the upper basement section and sediments matches the theoretical value.

Based on the analysis of Robertson and Peck (1974), this discrepancy is probably not an artifact of the particular porosity-conductivity model used. However, it could easily be a result of errors in determining the least reliable parameter in the calculations, the temperature gradient deeper than $900 \mathrm{~m}$. Both estimates of this gradient-the first from the extrapolation of Leg 83 temperature logs, and the second from two Leg 92 minimum temperature values - could have been subject to large errors. Since the Leg 92 gradient seems to be consistent with the preferred Leg 70 extrapolation shallower than $900 \mathrm{~m}$, it is tempting to speculate that the deep Leg 92 gradient, $0.08^{\circ} \mathrm{C} / \mathrm{m}$, may be a better estimate of the in situ value than the lower Leg 83 apparent gradient. The larger Leg 92 gradient gives better agreement with the heat flow determinations shallower than $900 \mathrm{~m}$. Despite the uncertainties in our determinations of the value of the gradient below $900 \mathrm{~m}$, our measurements show no evidence for heat transfer processes other than conductive.

\section{DISCUSSION-THE THERMAL AND HYDROLOGIC REGIME IN HOLE 504B}

The geothermal data presented here are consistent with a predominantly conductive mode of heat transfer in the relatively young oceanic crust in Hole 504B. The linearity of the basement gradients and the reasonable agreement of sediment and basement heat flows with the theoretical value argue against any significant removal of plate heat by hydrothermal circulation, either vertical or lateral. These results support conceptual models of the controlling role of the thickening sediment layer in sealing off hydrothermal circulation of ocean bottom water into the basement (e.g., Sclater et al., 1976; Anderson and Hobart 1976; Anderson et al., 1977). The sediment cover in Hole 504B is clearly thick enough to prevent open hydrothermal circulation between ocean bottom water and basement, as occurs closer to the spreading axis. However, our results are not inconsistent with possible continued convection confined to basement at slow rates and with little effect on the dominantly conductive vertical heat transfer in Hole 504B.

Superimposed on the conductive heat flow is a transient flow of ocean bottom water down the hole into the uppermost levels of basement. This flow was triggered 
Table 3. Summary of the correction of measurement data to estimate in situ thermal conductivity and heat flow.

\begin{tabular}{|c|c|c|c|}
\hline & Sediment & & Basement \\
\hline Depth interval (m) & $0-274.5$ & $400-900$ & $900-1300$ \\
\hline Gradient $\left({ }^{\circ} \mathrm{C} / \mathrm{m}\right)$ & {$[0.205]$} & $0.114 \pm 0.002$ & $\begin{array}{l}0.070 \pm 0.005(\text { Leg } 83) \\
0.08 \pm ? \quad(\text { Leg } 92)\end{array}$ \\
\hline \multicolumn{4}{|l|}{ Uncorrected values } \\
\hline $\begin{array}{l}\mathrm{K}_{\text {basalt }}(\mathrm{W} / \mathrm{m}-\mathrm{K}) \\
\text { Heat flow }\left(\mathrm{mW} / \mathrm{m}^{2}\right)\end{array}$ & & $\begin{array}{l}1.67 \pm 0.09 \\
190 \pm 13\end{array}$ & $\begin{array}{l}2.05 \pm 0.09 \\
144 \pm 17(\text { Leg } 83) \\
165 \pm ?(\text { Leg 92) }\end{array}$ \\
\hline \multicolumn{4}{|l|}{ Porosity } \\
\hline$\phi_{\text {bulk }}(\%)$ & & $7-10$ & $1-3$ \\
\hline$\phi_{\text {sample }}(\%)$ & & $3-5$ & $1-2$ \\
\hline \multicolumn{4}{|l|}{ Corrected values } \\
\hline \multirow{3}{*}{$\begin{array}{l}K_{\text {in situ }}(\mathrm{W} / \mathrm{m}-\mathrm{K}) \\
\text { Heat flow }\left(\mathrm{mW} / \mathrm{m}^{2}\right)\end{array}$} & {$[0.95]$} & 1.58 & 2.00 \\
\hline & $196 \pm 5$ & $181 \pm 20$ & $140 \pm 30($ Leg 83$)$ \\
\hline & & & $160 \pm 30($ Leg 92$)$ \\
\hline
\end{tabular}

Note: The correction procedure is described in detail in text. Bracketed sediment values are mean values determined from the heat flow measured in Hole 504C. Tabulated errors in uncorrected basement gradients correspond to standard errors in the gradient estimates determined in linear regressions of estimated equilibrium temperatures with depth (Fig. 4). Tabulated errors in uncorrected basalt conductivities are standard deviations of sample means. Errors in corrected heat flows were subjectively estimated.

when the sediment seal was penetrated during Leg 69 and was driven by the pressure differential between hydrostatic bottom water and underpressured basement pore waters. Similar downhole flow has been indicated by temperature measurements at several other DSDP holes, although not so clearly as in Hole 504B: Holes 335, 396B, 395A, and 556 on the flank of the Mid-Atlantic Ridge (Hyndman et al., 1976, 1977; Erickson and Hyndman, 1978; Becker et al., 1984; Hill and Cande, in press) and Hole 454A in the Mariana Trough (Uyeda and Horai, 1981). Based on the results at Hole 504B, we suggest that the downhole flow in these other holes is also due to underpressured basement, which may occur in young crust where it is locally or regionally overlain by a relatively thick sediment cover.

The origins of the basement underpressures in Hole 504B have not been directly determined, but a likely possibility is continued hydrothermal circulation confined to basement. Although the $274.5-\mathrm{m}$ sediment layer in Hole 504B may be an effective seal against hydrothermal circulation, it is not a strong barrier against diffusion within the pore fluids of pressure differentials between basement and hydrostatic bottom water. The time constant for "pressure diffusion" through the $274.5-\mathrm{m}$ ( $=L$ ) sediment layer is given by $L^{2} \phi \mu c / k$, with $\phi$ and $k$ the porosity and permeability of the sediment, and $\mu$ and $c$ the dynamic viscosity and compressibility of the pore fluid (essentially seawater). Using typical values of $\phi=0.8$ (Wilkens and Langseth, 1983), $k \approx 10^{-15}$ to $10^{-18} \mathrm{~m}^{2}$ (Bryant et al., 1975), $c \approx 4 \times 10^{-13} \mathrm{~m} \mathrm{~s}^{2} \mathrm{~g}^{-1}$, and $\mu \approx 0.8 \mathrm{~g} \mathrm{~m}^{-1} \mathrm{~s}^{-1}$ (Defant, 1961, p. 50), this time constant is on the order of 1-1000 yr. Therefore, relict underpressures cannot be maintained in the basement over longer periods of time, so a continuing process is probably responsible for the measured underpressure. Tectonic process with time scales much longer than 1000 yr. probably could not maintain basement underpressures against the relatively quick pressure diffusion through the sediments. This would seem to rule out the possibilities that the underpressures might have resulted from the subsidence of the cooling plate, or from sea-level changes associated with Pleistocene glaciation, or from crustal reheating caused by conductive re-equilibration as open hydrothermal circulation was sealed off by the thickening sediment cover.

Anderson and Zoback (1982) presented a model that demonstrates the feasibility of a cellular hydrothermal system, confined to basement, to explain both the basement underpressure and a possible $\pm 25 \mathrm{~mW} / \mathrm{m}^{2}$ amplitude variation in the surface heat flow within approximately $10 \mathrm{~km}$ of Hole 504B. Langseth and Mottl (1982) recently investigated this possibility and found lateral gradients in both surface heat flow and sediment pore water geochemistry, apparently caused by lateral convection within the basement. From the measured permeabilities and apparent porosities in Hole 504B (Fig. 7), we infer that any possible continuing circulation within basement should be confined to the section of basement shallower than $\sim 900 \mathrm{~m}$, below which the porosity, and presumably the permeability, sharply decrease.

The temperature measurements in Hole 504B provide no direct evidence for such hydrothermal circulation in the vicinity of the hole, although they allow the distinct possibility that the underpressure of basement pore fluids may ultimately be due to convection. Even if this is so, the downhole water flow bears no resemblance to the possible hydrothermal convection in the basement. The downhole flow is clearly pressure-driven, forced motion, not free, thermal buoyancy convection like that generally associated with large-scale hydrothermal circulation. If the basement underpressure could clearly be shown to be of hydrothermal origin, the downhole flow might properly be called "hydrothermal" in an indirect sense. However, the actual movement of water down the hole is an artifact of human interference with the natural situation and is not in itself hydrothermal convection. 


\section{ACKNOWLEDGMENTS}

With the exception of the addition of Leg 92 results, this chapter essentially reprints, with permission, an article published in the Journal of Geophysical Research (Becker, Langseth, Von Herzen, and Anderson, 1983) and copyrighted by the American Geophysical Union. We thank Captains Dill and Clarke and the very able crews of the Glomar Challenger for drilling and preserving the unique Hole 504B. The temperature measurements would not have been possible without the expertise of the skilled DSDP technical staff and the Gearhart-Owen and Schlumberger, field engineers. We thank Drs. R. Hyndman, A. Lachenbruch, and G. Bodvarrson for constructive reviews of various versions of this manuscript. We thank L. Boyce for expertly typing many versions of this paper. This study was supported by U.S. National Science Foundation Grants C-482 and OCE 81-17693.

\section{REFERENCES}

Anderson, R. N., and Hobart, M. A., 1976. The relation between heat flow, sediment thickness, and age in the eastern Pacific. $J$. Geophys. Res., 81(17):2968-2989.

Anderson, R. N., Honnorez, J., Becker, K., Adamson, A. C., Alt, J. C., Emmermann, R., Kempton, P.D., Kinoshita, H., Laverne, C., Mottl, M., and Newmark, R. L., 1982. DSDP Hole 504B, the first reference section over $1 \mathrm{~km}$ through Layer 2 of the oceanic crust. Nature, 300:589-594.

Anderson, R. N., Langseth, M. G., and Sclater, J. G., 1977. The mechanisms of heat transfer through the floor of the Indian Ocean. J. Geophys. Res., 82:3391-3409.

Anderson, R. N., and Zoback, M. D., 1982. Permeability, underpressures, and convection in the oceanic crust near the Costa Rica Rift, eastern equatorial Pacific. J. Geophys. Res., 87:2860-2868.

Becker, K., Langseth, M. G., and Hyndman, R. D., 1984. Temperature measurements in Hole 395A, Leg 78B. In Hyndman, R. D., Salisbury, M. H., et al., Init. Repts. DSDP, 78A: Washington (U.S. Govt. Printing Office), 689-698.

Becker, K., Langseth, M., and Von Herzen, R., 1983. Deep crustal geothermal measurements, Hole 504B, Deep Sea Drilling Project Legs 69 and 70. In Cann, J. R., Langseth, M. G., Honnorez, J. Von Herzen, R. P., White, S. M., et al. Init. Repts. DSDP, 69: Washington (U.S. Govt. Printing Office), 223-236.

Becker, K., Langseth, M., Von Herzen, R., and Anderson, R., 1983. Deep crustal geothermal measurements, Hole 504B, Costa Rica Rift, J. Geophys. Res., 88:3447-3457.

Becker, K., Von Herzen, R. P., Francis, T. J. G., Anderson, R. N., Honnorez, J., Adamson, A. C., Alt, J. C., Emmermann, R., Kempton, P. D., Kinoshita, H., Laverne, C., Mottl, M., and Newmark, R. L., 1982. In situ electrical resistivity and bulk porosity of the oceanic crust, Costa Rica Rift. Nature, 300:594-598.

Bryant, W. R., Hottman, W., and Trabant, P., 1975. Permeability of unconsolidated and consolidated marine sediments, Gulf of Mexico. Mar. Geotech., 1:1-14.

Bullard, E. C., 1947. The time necessary for a borehole to attain temperature equilibrium. Monthly Notices Roy. Astron. Soc., Geophys. Suppl., 5:127-130.

Burch, T. K., and Langseth, M. G., 1981. Heat flow determination in three DSDP boreholes near the Japan Trench. J. Geophys. Res., 86:9411-9419.

Cann, J. R., Langseth, M. G., Honnorez, J., Von Herzen, R. P., White, S. M., et al., 1983. Init. Repts. DSDP, 69: Washington (U.S. Govt. Printing Office).

Carvalho, H. da S., Purwoko, S., Thamrin, M., and Vacquier, V., 1980. Terrestrial heat flow in the Tertiary basin of central Sumatra. Tectonophysics, 69:163-188.

Clark, S. P., Jr., 1966. Thermal conductivity. In Clark, S. P., Jr. (Ed.), Handbook of Physical Constants Mem. 97: New York (Geological Society of America), pp. 459-482.

CRRUST (Costa Rica Rift United Scientific Team), 1982. Geothermal regimes of the Costa Rica Rift, east Pacific, investigated by drilling, DSDP-IPOD Legs 68, 69, and 70. Geol. Soc. Am. Bull. 93: 862-875.

Defant, A., 1961. Physical Oceanography, (Vol. 1): New York (Pergamon Press).

Erickson, A. J., and Hyndman, R. D., 1978. Downhole temperature measurements and thermal conductivities of samples, Site 396 Deep
Sea Drilling Project Leg 46. In Dmitriev, L., Heirtzler, J., et al., Init. Repts. DSDP, 46: Washington (U.S. Govt. Printing Office), 389-400.

Erickson, A. J., Von Herzen, R. P., Sclater, J. G., Girdler, R. W., Marshall, B. V., and Hyndman, R., 1975. Geothermal measurements in deep-sea drill holes. J. Geophys. Res., 81:4042-4052.

Hill, I. A., and Cande, S. C., in press. Thermal measurements and seawater downflow into 35-Ma-old oceanic crust, central North Atlantic. In Bougault, H., Cande, S. C., et al., Init. Repts. DSDP, 82: Washington (U.S. Govt. Printing Office).

Hyndman, R. D., and Drury, M. J., 1976. The physical properties of oceanic basement rocks from deep drilling on the Mid-Atlantic Ridge. J. Geophys. Res., 81:4042-4052.

Hyndman, R. D., Von Herzen, R. P., Erickson, A. J., and Jolivet, J., 1976. Heat flow measurements in deep crustal holes on the MidAtlantic Ridge. J. Geophys. Res., 81(23):4053-4060. 1977. Heat flow measurements, Deep Sea Drilling Project Leg 37. In Aumento, F., Melson, W. G., et al., Init. Repts. DSDP, 37: Washington (U.S. Govt. Printing Office), 347-362.

Jaeger, J. C., 1956. Condition of heat in an infinite region bounded internally by a circular cylinder of a perfect conductor. Aust. J. Phys. 9:167-179.

1961. The effect of the drilling fluid on temperatures measured in boreholes. J. Geophys. Res., 66: 563-569.

1965. Application of the theory of heat conduction to geothermal measurements. In Lee, W. H. K. (Ed.), Terrestrial Heat Flow: Washington (American Geophysical Union), pp. 7-23.

Karato, S., Wilkens, R. H., and Langseth, M. G., 1983. Shipboard physical properties measurements of basalts from Costa Rica Rift, Deep Sea Drilling Project Legs 69 and 70. In Cann, J. R., Langseth, M. G., Honnorez, J., Von Herzen, R. P., White, S. M., et al., Init. Repts. DSDP, 69: Washington (U.S. Govt. Printing Office), 675682.

Lachenbruch, A. H., and Brewer, M. C., 1959. Dissipation of the temperature effect of drilling a well in Arctic Alaska. J.S. Geol. Surv. Bull. 1083-C, Washington (U.S. Govt. Printing Office).

Langseth, M. G., Cann, J. R., Natland, J. H., and Hobart, M., 1983. Geothermal phenomena at the Costa Rica Rift: Background and objectives for drilling at Deep Sea Drilling Project Sites 501, 504, and 505. In Cann, J. R., Langseth, M. G., Honnorez, J., Von Herzen, R. P., White, S. M., et al., Init. Repts. DSDP, 69: Washington (U.S. Govt. Printing Office), 5-30.

Langseth, M. G., and Mottl, M., 1982. Geochemical and geothermal mapping of crustal circulation patterns near DSDP Sites 501/504. EOS, 63:1116. (Abstract).

Leinen, M., Rea, D. K., et al., in press. Hole 540B. In Leinen, M. Rea, D. K., et al., Init. Repts. DSDP, 92: Washington (U.S. Govt. Printing Office).

Lesem, L. B., Greytok, F., Marotta, F., and McKetta, J., Jr., 1957. A method of calculating the distribution of temperature in flowing gas wells. Pet. Trans., AIME, 210:169-176.

Lister, C. R. B., 1977. Estimators for heat flow and deep rock properties based on boundary layer theory. Tectonophysics, 41:157-171.

Mottl, M. J., Anderson, R, N., Jenkins, R. N., and Lawrence, J. R., 1983. Chemistry of waters sampled from basaltic basement in Deep Sea Drilling Project Holes 501, 504B, and 505B. In Cann, J. R., Langseth, M. G., Honnorez, J., Von Herzen, R. P., White, S. M., et al., Init. Repts. DSDP, 69: Washington (U.S. Govt. Printing Office), 475-484.

Parsons, B., and Sclater, J. G., 1977. An analysis of the variation of ocean floor bathymetry and heat flow with age. J. Geophys. Res., 82 (5):803-827.

Ratcliffe, E. H., 1960. The thermal conductivities of ocean sediments. J. Geophys. Res., 65 (5):1535-1541.

Reynolds, O., 1883. On the experimental investigation of the circumstances which determine whether the motion of water shall be direct or sinuous, and the law of resistance in parallel channels. Phil. Trans. Soc. London, 174:935-982.

Robertson, E. C., and Peck, D. L., 1974. Thermal conductivity of vesicular basalt from Hawaii. J. Geophys. Res., 79:4875-4888.

Sass, J. H., Lachenbruch, A. H., and Munroe, R. J., 1971. Thermal conductivity of rocks from measurements on fragments and its application to heat-flow determinations. J. Geophys. Res., 76:33913401 . 
Schlichting, H., 1968. Boundary-Layer Theory: New York (McGrawHill Book Company).

Schloessin, H. H., and Dvorak, Z. D., 1977. Physical properties of samples from the JOIDES, Leg 37, Deep Sea Drilling Project. In Aumento, F., Melson, W. G., et al., Init. Repts. DSDP, 37: Washington (U.S. Govt. Printing Office), 403-415.

Sclater, J. G., J. Crowe, and R. N., Anderson, 1976. On the reliability of oceanic heat flow averages. J. Geophys. Res., 81 (17):2997-3006.

Stephen, R. A., 1983. The oblique seismic experiment on deep Sea Drilling Project Leg 70. IN Cann, J. R., Langseth, M. G., Honnorez, J., Von Herzen, R. P., White, S. M., et al., Init. Repts. DSDP, 69: Washington (U.S. Govt. Printing Office), 301-308.

Stephen, R. A., Harding, A. J., 1983. Travel time analysis of borehole seismic data. J. Geophys. Res., 88:8289-8298.

Uyeda, S. and Horai, K., 1981. Heat flow measurements on Deep Sea Drilling Project, Leg 60. In Hussong, D., Uyeda, S., et al., Init.
Repts. DSDP, 60: Washington (U.S. Govt. Printing Office), 789802.

Von Herzen, R. P., and Maxwell, A. E., 1959. The measurement of thermal conductivity of deep-sea sediments by a needle-probe method. J. Geophys. Res., 64:1557-1563.

Wilkens, R. H., and Langseth, M. G., 1983. Physical properties of sediments of the Costa Rica Rift, Deep Sea Drilling Project Sites 504 and 505. In Cann, J. R., Langseth, M. G., Honnorez, J., Von Herzen, R. P., White, S. M., et al., Init. Repts. DSDP, 69: Washington (U.S. Govt. Printing Office), 659-674.

Woodside, W., and Messmer, J. H., 1961. Thermal conductivity of porous media, 1. J. Appl. Physics, 32:1688-1699.

Yokota, T., Kinoshita, H., and Uyeda, S., 1980. New DSDP (Deep Sea Drilling Project) downhole temperature probe utilizing IC RAM (memory) elements. Earth Res. Inst. Tokyo Bull., 54:441-462.

Date of Acceptance: 25 October 1983 